Plebejskie „potkania” z niechcianym żołnierzem — na przykładzie wybranych komedii polskich z początku XVII wieku

Piotr Pirecki 


\section{Piotr Pirecki}

\section{Plebejskie ,potkania” z niechcianym żołnierzem - na przykładzie wybranych komedii polskich z początku XVII wieku}

$\mathrm{N}$ ajpierw drobne wyjaśnienie. „Potkanic” nie jest s p o t k a n i e m, a jeśli, to tylko przypadkowym i konfrontacyjnym. w zgietku bitewnym. Calkowicie bez towarzyskiego wątku oraz bez widoków na przyszłość, sprawność osiąga jedynie w zderzeniu z trudną rzeczywistościa, która drobne potyczki podnosi do rangi wartej literackiego upamiętnienia. Aż do tego stopnia, że ..potkanie" stało siç motywem przewodnim dwu plebejskich komedii z początkı XVII w., pracowicie zebranych przez Karola Badeckiego we wspólnym tomie Komedia n'battourka!. Sam termin „komedia plebejska” zastępuje dotychczasowy "rybaltowska” ze względı na bardzicj pojemmą formulę terminologiczną, która lepiej przystaje do zawartości poszczególnych utworów i która w pełni oddaje bogactwo świata ludowego na wspak wbrew wszystkiemu i wszystkim. W tym paradygmacie mieści się w szczególności interesująca nas postać żołnierza, jak okazuje się w praktyce - zołnierza zgola przypadkowego, zdegradowanego i zdegenerowanego. Nasze rozważania idą tym właśnie szlakiem, pokazıjąc, ze niektóre spośród komedii plebejskich bawią siç groteskową, acz niebezpieczną figurą żołnierza, ale równicż i ostrzegają przed licznymi niebezpieczeństwami, między innymi przed wszczynaniem burd przez skonfederowanych, którzy nagle, nawet bez własnej winy, zostali postawieni poza nawias społeczeństwa i w nowej dla sicbie sytuacji nie bardzo potrafili się odnaleźć. Na dodatek spotykali się, całkiem zresztą słusznie, z niechęccią clıłopów, którzy zatroskani o swój dobytek potrafili z determinacją walczyć o wlasne dobra, rabowane przez nickar-

\footnotetext{
I W tomic zébranc zostaly różnomicnne utwory. nicraz nietrafnic wlączone w ranyy ..rybattowskie" (np. po-

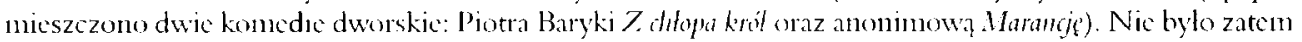
metodologii. która klasyfikowalaby utwory do wybrancgo paradygunatu (por. Polska komedia rytuattou'ska. opr. K. Badecki. Lwow 1931).
} 
ne wojsko i licznych maruderów. Ten problem nabrzmiewał, aż znalazł dość zabawne, ale i pouczające ujęcie w komediach. W świecie pelnym sprzeczności, na opak i w rozkroku, gdy "potkanie" wcale nie jest spotkaniem², i gdy liarmider wszczynany w wiejskim kurzu goracego, letniego poranka przez biegajace w bezladzic kury bywal nic do zniesienia, a w dodatku rwetes wywolywany histerią kobict zatroskanych obawą utraty godności tworzył obraz zgola niezwykły, potężnego chaosı i niemal konica świata, poza którym istnicje juz tylko pickło. A wszystko za sprawa winowajcy wszystkich nieszczęść - polskiego żołnierza, głodnego i obdartego, ktöry wreszcie zgiełk bitewny zapragną̧ zamienić na domowe zacisze, ale który najpierw musiat odbyć dlugą drogę wiodącą przez wiejskie podwórza.

A okazji do grabiczy nic brakowało. Rabunkom sprzyjała specyficzna i zgola nietypowa sytuacja społeczna. W początkach XVII w. wśród przyczyn licznych nieszczęść nawiedzających Rzeczpospolitą wymieniało się brak ze strony władzy królewskiej zainteresowania położeniem wojska, które po wojnach i kontliktach, trapiących notorycznie ojczyznę, pozostawało bez środków do życia i bez zawodowych perspektyw. Jeszcze dobrze wyglądała sytuacja wśród szlachty, która miała dokąd wrócić, ale żołnierze niskiego stanu nierzadko przedłużali sobie stan wojennej tułaczki, i wówczas ich aktywność zwracała się nie przeciw najeźdźcom, a przeciw pobratymcom, których niemilosicrnie hupili z i tak z ubogiego dobytku. To byl problem narastający przez całą pierwszą połowę XVII w. Aż dziw bierze, że polski sejm, tak bardzo rozgorączkowany i rozpolitykowany, nie bardzo umial znaleźć wyjście z zaistnialego konfliktu, w każdej chwili grożącego wybuchem wojny domowej lub, na szczęście tylko, lokalnych potyczek ${ }^{3}$.

Zastanawia również fakt dosyć wątlego odbicia owej problematyki w bogatej tematycznie grupie komedii plebejskich. Niewiadome były powody tak zdawkowego potraktowania spraw nurtujących głównie środowisko chlopskie. Być może ciagle słabą reprezentacją w baroku i słabo slyszalnym glosem, któremu nośność próbowały nadać dwie spośród wielu komedii - chyba najlepsza literacko Komedia rybattouska nou'a (1615) oraz Niepospolite mizenie, abo gessia wojna (1621). Kontekst społeczny obu utworów był podobny, różnice dotyczyły jedynie kwestii stricte wojennycl - Komedia njatrou'ska nom'a wprowadza kontekst reperkusji społecznych sławnej II Dymitriady (okres 1608-1613), gdy pozostawione samemu sobie niekarne wojsko, już po przekroczeniu granic Rzeczpospolitej, dokonywalo zajazdów i gwaltów na ludności polskich wsi i miasteczekt. Tacy whaśnie maruderzy byli prawdziwym utrapieniem - nic dosyć ze pozbawieni zludzeń i jakichkolwiek nadziei, nie mieli zadnych skrupułów, aby kradzież i rozbój uczynić źródlem utrzymania, to jeszcze wykazywali się wobec wlościan wyjątkową brutalnością. Przerazenie rozpasaniem konfederatów, którzy postępowali niczym

\footnotetext{
'Sam termin potkanic ponadal w' staropolszczyźnic rozległą semantykę̧ oraz bogaty waclılarz rozwiązań frazeologicznych. Wiele było definicji slowa porkanite. dla naszych celów najważnicjsze są dwa - 1. "zgromadzenic',

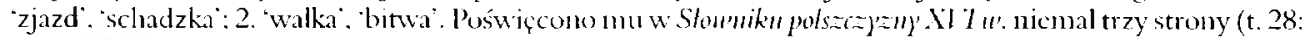
Poskakac - potzkanic', red. K. Wilczewska. L. Woronczakowa, Warszawa 2000, s. 377-379),

' Zob. J. Topolski. Dzicje Polski. Warszawa 1976, s. 282.

+ Ihidem. s. 283.
} 
szlacheccy "sobiepanowie” wszędzie tann gdzie pojawiali się natrętui zloczyńcy rodem z rozformowanego wojska, budziła ich determinacja w ucieczce przed glodem i coraz powszeclunicj dosięgającą nędzạ̄.

Na pewną bierność i bezradność polskiego sejunu i króla wobec konfederackich zaborów wiejskiego mienia plebejusze reagowali na szczęście w sobie tylko znany i umiejętny sposób. Wiedząc, że prawdziwa terapia kryje siç w śmiechu, postanowili na nieprawości tegro świata i jego bolesne sprawy reagować z lekkością, z przymrużeniem oka i na wspak". Tematyka komediowa (Komedia rybatton'ska nom'a) byla zwykle podobna - konfederat przybywa do wioski, w której panuje glód (rozmowa Magistra i Kantora z Gospodarzem), ale nawet i taki stan rzeczy nie przeciwdziatal rozbojom i kradziczom. Wręcz przeciwnic - stanowil dosyć przewrotną i specyficzną zachętę do czynienia zla, na które istniało dość powszechne przyzwolenie, a może tylko spoleczna obojętność. Jako jeden z cudem ocalałych z. moskicwskicj rzezi lisowczyków (sam o sobie powiada. że jest ..moskwicinem”) zdobył przeświadczenie o whasnej bezkarności i postępowaniu w zgodzic z ustanowionym tylko przez siebie kodeksem mlodzicńca-barbarzyńcy.

Termin „konfederat” w drugim dziesiątku lat XVII w. nabrał znaczenia pejoratywnego i nieco blazeńskiego, wlaśnic na wspak, gdy w poważną tematykę wpleciony zostaly nieszczęsne losy karykaturalnie ośmieszonego bolatera. Wcale lub prawie wcale nie oznaczat tylko stronnika konfederacji, ale każdego pospolitaka, który odważył siç mienić żolnierzem.

„Potkanje” w Kontedii mpaltou'skiej nou'ej nieni się wielobarwnym pejzażem kontliktów, whtóre z konieczności whraczali bohaterowie utworu. Od sannego początku na plan pierwszy wysuwala się niespodziewana perswazja erystyczna, której charakterystycznym znamieniem byla dążność do opanowania sytuacji wewnątrz dramatycznego konfliktu. Od samego początku jego oś symetrii przebiegala konsekwentnie: Gospodarz, Gospodyni, Kantor i Klecha reprezentowali wicjska społeczność, na przeciwległym biegunie sytuowal się samotny Konfederat. Zarzewiem wszystkich perypetii i zdarzcń byly slowa Gospodarza, które odnosily się do wcześniejszych nieszczęść związanych z przemarszem moskiewskich wojsk, a jednocześnie będące zwiastunem tego, co dopiero nastappi, z wiclokrotnie więliszą intensywnością:

Obrócili domostwo, zjedli kury, gąski.

Brogi puste, stodoly; owce, woly, skopy

Potrawili, do znaku wyniszczeli chlopy.

Bodaj się byli z Moskwy nigdy nie wrócili,

Nizeli nas, tubogie, wniwecz obrócili (w. 6(1)-65).

Esencjonalna wypowiedź Gospodarza pokazuje ogrom zniszccení, jakich dopuściło siç wojsko we wsiach będących na drodze ich stacji. To nicmalże ludowa Apokalipsa bez udziału

5. Tak zwal siç szlachcic należacy do kontederacji, ale potocznic kazdy zuch , do korda i puchara, śnialck z dziclną nimą i odwazną wymową" (por. Z. Ciloger, hasto: Konfederat w: idem. Lncyklopedia sturopolska, wst. J. Kızyzanowski, t. 3. Warszawa 1978, s. 76.

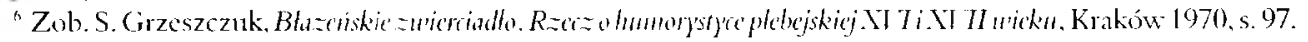


sil nadprzyrodzonych, pozostawiająca wlościan na pastwę losu i bez nadziei na poprawę egzystencji. Dużo w nicj emocji mającej związek ze sztukį retorycznej perswazji, ale nade wszystko wyziera na powierzchniç ton racjonalnego uporządkowania wydarzeń, ton racjonalnej harmonii. Posiadał on pierwszorzędną wage — bez próby racjonalnego opanowania mikrorzeczywistości wiejskiego podwórza niemożliwe byloby pogodne przetrwanie, jakże charakterystyczne dla środowiska plebejskiego, nawet abstrahując od tego, że obcujemy ze światem komedii. To emocja pozbawiona dystynktywnych znamion, emocja będąca wynikicm pogodzenia z losem, bo przecicż zmian nie należy się spodziewać. Są raczej niemożliwe, a na niesprawiedliwość trzeba reagować śmiechem oswajającym i swobodnym, śmiechem-ratumkiem przed kalekim urządzeniem świata ${ }^{7}$. To dopiero zarys takicj postawy; uzyska ona w dalszej części calkowite rozwinięcie i akceptację środowiska plebejskiego.

Chęć racjonalnego opanowania rodzącego siç w pełni konfliktu prowokuje Konfederatę, który wręcz nie potrafi pogodzić siç z faktem, ze jego pojawienie we wsi nie wywołuje strachu, a przeciwnie - jednoczy wlościańską społeczność. To stawia go na pozycji przegranej, i sam z napastnika i lowcy staje się ofiarą sytuacji, w jaką zabrnął z błędnego rozeznania rzeczywistości i swoich, dosyć wątłych, możliwości. Znakomite są słowa Konfederaty, wyraz prowokacyjnej perswazji, mającej na celu wywołanie u plebejuszy współczucia i zalu. Zatem znów emocjonalny ton, tym razem jednak wyraża bezradność wojaka wobec wiejskiej wiçkszości. Gdy powracal myślami do, ,utarczek z Moskwą” (w. 145), wówczas na plan pierwszy wybijaly się takie oto turpistyczne obrazy — reminiscencje II I ymitriady, szczególnie makabryczne akty kanibalizmu:

Jeśli pies albo kotkia, żarliśny, co dano.

Zjadl drugi udziec więźnia, jak najlepszej sarny, Wzdychając, biadat na się, i na ten czas marny ${ }^{8}$ (w. 152-154).

Nie dziwi więc zdeformowana i zdegrradowana psychika Konfederaty. Po takich przeżyciach jasne się staje, że zatarciu ulegla jego wrażliwość, że normą postępowania stała się macliaweliczna zasada celı uświęcającego środki. Tyle że komedia świetnie pokazuje liczne sposoby walki z wojskowymi maruderami-pieniaczami, i czyni to w formie przypominającej słynną Rejową Rozpran'c między trzéma osobami. Narzekania Konfederaty na moskiewską rzeczywistość od razu zbijane są równie dramatycznymi opowieściami o gwaltach i samowolach żołnierzy, dla których fraszką było zadawanie krzywd bezbronnym plebejuszom:

Co się im od żołnierstwa krzywd gwalt zadzialato!

Nie zachodząc daleko, w Luborzyczy klecha,

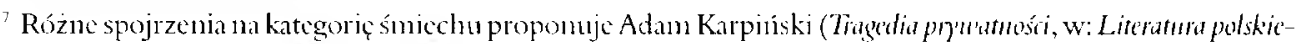

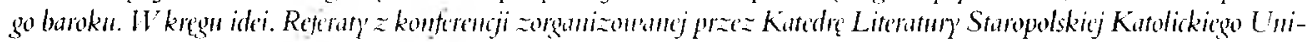

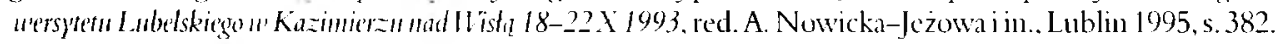

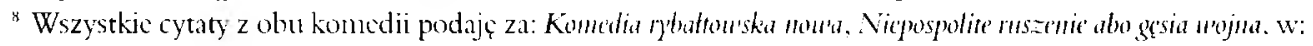
Polska komedia iglobouska, ap. it..
} 
Stanislaus on wielki, trzy wierdunki z miccha

Tak nu pięknie wymknçli, w drodze go potkawszy.

Horrende go obuszki po grabiecie wezbrawszy.

Na kogoz miał iść skarżyć, wiatr po świecie tapać,

Musial się do wsi z placzem nieboras przyczlapać (w. 165-170).

W sofistycznyı sporze, gdzie jeden argument zostaje zastapiony kontrargumentem, trudno uzyskać przewagę i zwycięsko wyłożyć swoje racje. A jednak tak jest tylko na pozór. Komedie zawsze przedstawiają stanowisko bliskie autorowi bądź środowisku ludowemu akcent subicktywnej sympatii decyduje więc, czyje racje okazują się zwycięskie i jaki z nich wynika pożytek dla ogółu". In bardziej plebejscy bohaterowie przerzucają się argumentami udowadniającymi żohnierskie nieprawości, tym (zęścicj powstaje wrażenie zorganizowanego chaosu i anarchii prowadzącej do wniosku, że wreszcie pora położyć kres gwaltom i zajazdom i dać dobra nauczkę Konfederatowi. Powodów, aby nauczyć zuchwalego zołnierza moresu, bylo nader wiele, przede wszystkim bardzo czçste ,stacyje”, wykorzystywane przez niekarne wojsko w nadmiarze ${ }^{11}$. Kantor, przerażony perspektywą Rzeczpospolitej w okowach materialnych roszczeń armii zdemoralizowanych maruderów, rozsnuwa niepokojący obraz kraju owładniętego niemoca. Znow w formie parodystycznego wynaturzenia i amplifikacyjnej deformacji, aby możliwie jak najdokładniej przedstawić śmicchem i karykaturą bezwhad Rzeczpospolitej:

Ale wasze, w Zielonkach bioręcy stacyją,

Wziçli też Symonowi petycyja.

Nuż Ioannes, żak dobry, cow Bolechowicach,

Potym i Krystoferus w Raciborowicach,

Ci wszyscy narzckają; także i z Pleszowa [...] (w. 185-187).

Zabór mienia był wiçc zjawiskiem powszechnym, moźna domnienywać, że dla niektórych spośród żołdaków intratnym sposobem na życie - jak w przypadku plebejuszy publiczna blazenada i żcbractwo.

Właśnie żart stanowi najbardziej dogodne i skuteczne anticłotum na bolączki wywołane najazdami. I nie tylko dlatego, ze tak nakazuje konwencja komedii. Plebejusze w ten sposób odciagaja „zle moce”, poprzez kulturę śmiechu realizuja swoje przestanie radosnego aktywizmu wbrew wszystkiemu i wszystkim, nawet na przekór ciçżkim czasom i njewesolej sytuacji. Śmiech ratuje przed bezradnością i brutalnością, cywilizuje i dodaje odwagi, pozwala lączyć antynomie. W dialogu z Konfederatem Magister okizuje się od niego o wiele sprytniejszy, a dziçki temu wytycza ścieżki postępowania wobec uciązliwego gościa. Nawet zdobywa

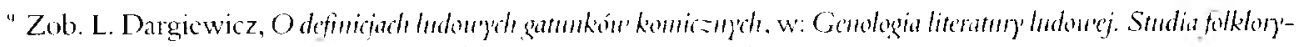
stye $\approx m$. red. A. Mianecki. V. Wróblewska. Torun 2002. s. 154-156.

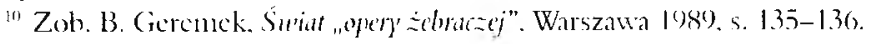


się na akt nie byle jakiej odwagi, gdyz kıytycznie recenzuje nazbyt częste nakladanie przez żolnierza szatek niewinności -

I ty tego nie wkładaj na konfederaty,

Mogło tam być luultajstwo, a nie nasze roty (w. 181-182) -

postanawia rzecz calą zamknąć pijaństwem na zgodę w gospodzic.

Komedia nie bylaby komedią, gdyby nie nagle i niespodziewane komplikacje, które pojawiają się jak dens ex machina, i to w samym zakończeniu niezwykłego utworu. Pojawienie I)ziada i Baby, „podobnych diablom”, wywoluje u Konfederaty prawdziwy niepokój, zaś Kantor, Klecha i dzwonnik nabicrają odwagi i postanawiają nauczyć wojaka-nicponia moresu, szarpiąc go i bijąc. gdzie popadnie:

Kantor konfederata ujmie za ramiona z tyłu, a dzwonnik za szablę, klecha też do gęby z pięścią.

Taki niebywaly akt zbiorowej odwagi wobec uzbrojonego przybysza ma wyraźnie sygnalizowane przesłanie, a brzmi ono, że nie należy przeciwstawiać się zdeterminowanym plebejuszom, gdyz dla wyrządzającego krzywdę rzecz cala może się źle skończyć. Jak się okazuje, argumentacja była bardzo skuteczna, skoro Konfederat zrezygnował z kradzieży, błagając tylko swyclı oprawców o litość:

Dlugoż mie tak będziecie sobie poniewierać?

Czy podobno z moich szat cheecie muie obdzierać? (w. 325-326).

Komedia nie poprzestaje wyłącznie na mauce Konfederaty zasad właściwego postępowania w jedynie skutecznej postaci - poprzez bijatykę. Idzie znacznie dalej — pobity żolnierz radykalnie zmienia swe stanowisko, i wręcz mówi, że będzie optował za zniesieniem stacji wojskowych, co jest humorystycznym przejawem ostatecznego zwycięstwa plebejuszy:

Pomówię z towarzystwem, skoro się zjedzienny,

Aza też z tego sejmu placa miéć będziemy.

Słyszę, uniwersaly do nas rozpisano,

Zeby już więcej stacyj z województw nie brano (w. 406-4(19).

Zatem od rozpaczy do zwycięstwa. Okazıje się bowiem, że w komedii wszystko jest na opak, inaczej niż w życiu. Bezkarny żołnierz nie może czuć się pewnie, gdy spotyka się z gromadą zdeterminowanych plebejuszy przygotowanych na wszystko. To groźne ostrzeżenie dla stacji wojskowych, że czas ich bezkarności bezpowrotnie przeminąl i pozostaje tylko kompromis jako mctoda rozwiązywania naroslych problemów.

W konwencji wylącznie żartobliwej pojawila się kwestia „gęsich żolnierzy” — nicponiów w Niepospolitym ruszeniu abo gesicj wojnie (1621) Jana I)zwonowskiego. Gdy przed laty polska historia i spektakularnic zoricntowana polska karykatura kreowała wizerunek ,kokoszych ry- 
cerzy” i „wojny kokoszej”, wówczas nikt nie przypuszczał, że dalckic echo faktycznych wydarzeni z roku 1537 pojawi się w odbitym lustrze plebejskich komedii, przefiltrowane dodatkowo przez krzywe zwierciadło. „Wojna gęsia” żywo przypomina wydarzenia sprzed lat — ten sam rodzaj „niepospolitego ruszenia” — wojaków z dziarską miną uzbrojonych w kije, którym niestraszne byly ani liście na drzewach, ani sady, wreszcie drzewa owocowe. Obraz zgola heroikomiczny, ozdobiony petnymi zartobliwego realizmu przykładami:

Bralić mi i w ogrodzie, darlić mi i śliwy.

Zwłaszcza owi ijacy, odarta piechota,

Nie masz sam nic dobrego, kazdy z nich niecnota (w. 29-31).

Ale wojna nie jest tylko dalekim echem przeszłości, w rytmie codziennego życia sięga niemal chłopskich opłotków (..podobno tu Tatarzy byli kędyś blisko”). Nawet i wtedy nie zapominano o zakładaniu po wsiach stacji, które miały niewiele wspólnego z przygotowaniami do wojny w obronie Rzeczpospolitej, wiele natomiast z gwaltami na micjscowej ludności. Zwlaszcza zagrożone były młode dziewczęta:

Do brogów szturmowali, a zwozili harce,

Nie dali się 11 a piec u wyspać i kucharce (w. 62-63).

Utwór na tle twórczości komediowej XVII w. wprowadza jeden calkowicie nowy wątek. Jest nim realistyczny obrazek z życia parobka, który wzbudzil niechęć włościan porzuceniem pracy w polu po przylączeniu siç do gromady zbicdnialych wojaków. Szybko stał się jednym z nich, przcjął wojskowe obyczaje i rytuały, niewystawiajace bylemu parobkowi najlepszego świadectwa:

Był parobek, zuclıwalec, juz prawie nienaly.

Dzicwce zlość wyrządziwszy, poszedl za swą wolą,

Wolat sięz z nimi powlec. niźli orać rolą (w. 69-71).

Zohnierz-zuchwalec rzadko kiedy gości nal kartach naszej literatury, tym bardziej więc cenna jest figura parobka - intruza i burzyciela feudalnego porządku, który odrzucił grabie i widły, i udal się w drogę wraz z żohnierzanni. Ewidentny dowód na latwość spolecznego awansu bez wątpienia, tym bardziej oczywistego, że w krainie przemocy parobek czuje się jak u siebie $w$ domu.

Tak wszechstronny obraz wojskowych niegodziwości, rozpatrywanych z pozycji ludu, mógł wyjść tylko spod ręki pisarzy plebejskich. 1)ziçki nim wprowadzeni zostaliśmy w świat kaleki i wykolejony, w którym rządzą nie prawa stanowione, ale siła. Wiadomo że taki porządek unusial spotkać się z ostrą reakcją zainteresowanych.

Zaskakuje bogactwo skojarzeń plebejuszy związane z zołnierskimi awanturami i burdami. Realizm udanie współgra z heroikomicznym ośmieszeniem, patos i powaga z. wynaturzającą groteską i parodią; slowem, powstaje mieszanka przcróżnych, sprzecznych ingrediencji. 
W nim doskonale widać inteligencję komediopisarzy - skłonność do opanowania rzeczywistości wymykającej się racjonalnemu poznaniu, w htórej nie ma miejsca na gwałty zadawane bratı. Jeśli świata nie można ogarnąc rozumem, to pozostają intuicja i zmysły, rzadko kiedy prowadzące do falszywych ocen. Stąd wlaśnie wyrosła plebejska kultura śmicchu, będąca swictną odtrutką na swiat w swych formach zdegradowany i wykolejony, urzeczywistniony wylącznie w konwencji na opak. Tylko w ten sposób daje się oswoić i poznać. 